\title{
Polyarteritis nodosa presenting with bilateral cavernous internal carotid artery aneurysms
}

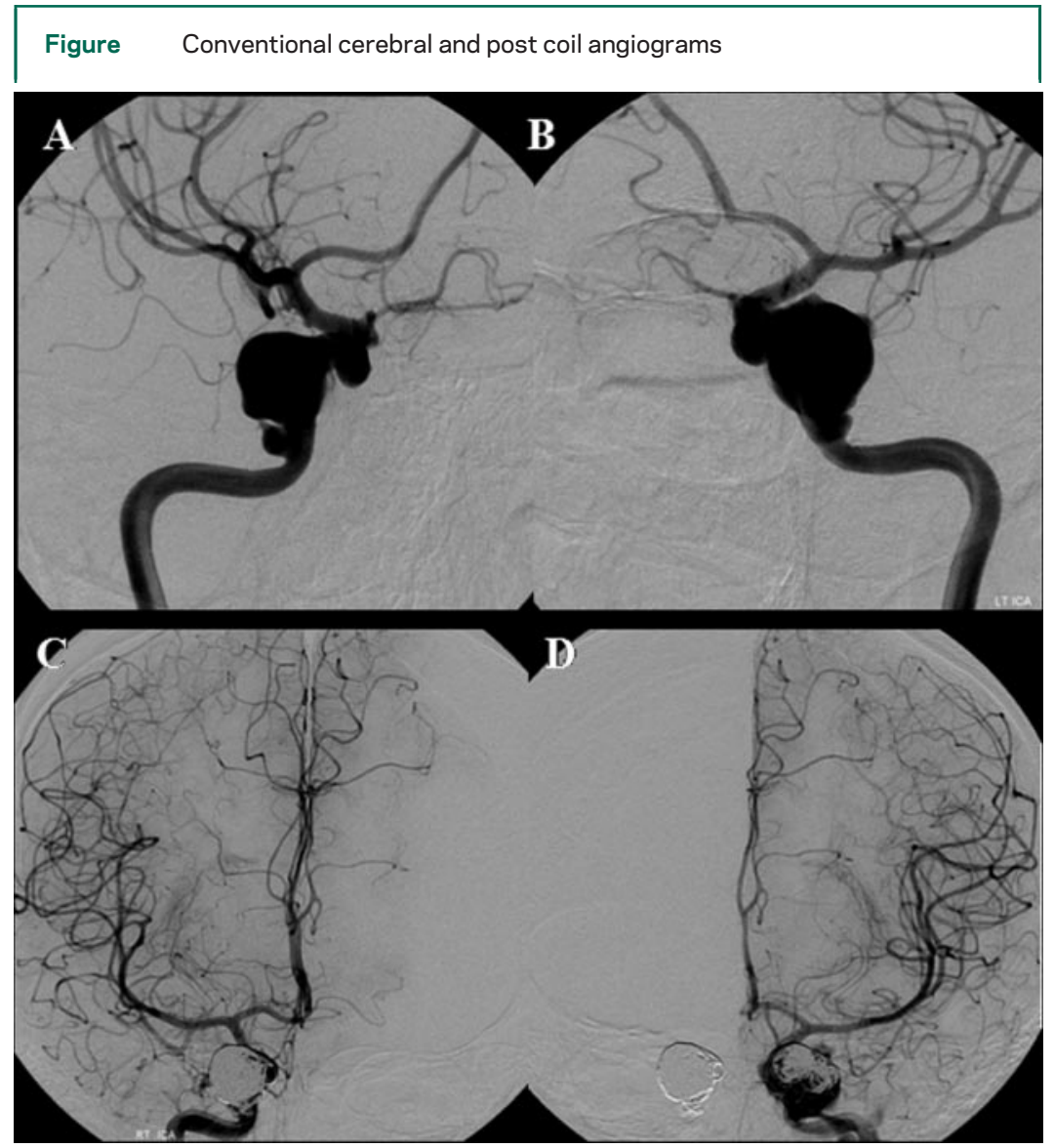

Conventional cerebral angiograms show bilateral internal carotid artery aneurysms on the cavernous portion, measuring $2.4 \mathrm{~cm}$ on the left side and $2 \mathrm{~cm}$ on the right (A, B). Post coil angiograms show successful occlusion and exclusion of the bilateral cavernous ICA aneurysms from the circulation $(C, D)$.

A 24-year-old man was admitted with a severe, abrupt-onset headache and diplopia. On neurologic examination, movement of the left eye was limited in all directions, while the right eye was limited on lateral gaze. Cerebral angiography demonstrated bilateral aneurysms on the cavernous portion of the internal ICA, measuring $2.4 \mathrm{~cm}$ on the left and $2 \mathrm{~cm}$ on the right (figure, A and B). Abdominal angiography showed multiple microaneurysms in the hepatic, renal, and adrenal arteries. Based on the criteria for the classification of polyarteritis nodosa (PAN), ${ }^{1}$ a diagnosis of PAN was made. Successful endovascular treatment was performed with stent insertion and a GDC coil for the right ICA aneurysm and a GDC coil for the left ICA (figure, C and D). To our knowledge, no case of bilateral cavernous internal carotid aneurysms has been reported. We describe the first case of bilateral cavernous internal carotid aneurysms in PAN presenting with bilateral ophthalmoplegia.

M.S. Oh, MD, M.H. Kim, MD, M.K. Chu, MD, K.H. Yu, MD, K.H. Kim, MD, and B.C. Lee, MD, Anyang City, Republic of Korea

Supported by a grant from the Korea Health 21 R \& D Project, Ministry of Health and Welfare, Republic of Korea (A060171). Disclosure: The authors report no conflicts of interest.

Address correspondence and reprint requests to Dr. Byung-Chul Lee, Department of Neurology, Hallym University Sacred Heart Hospital, 896 Pyungchon, Anyang City, 431-070, Republic of Korea; ssbrain@hallym.ac.kr

1. Lightfoot RW Jr, Michel BA, Bloch DA, et al. The American College of Rheumatology 1990 criteria for the classification of polyarteritis nodosa. Arthritis Rheum 1990;33:1088-1093. 


\section{Neurology}

\section{Polyarteritis nodosa presenting with bilateral cavernous internal carotid artery aneurysms}

M. S. Oh, M. H. Kim, M. K. Chu, et al. Neurology 2008;70;405

DOI 10.1212/01.wnl.0000298726.31304.be

\section{This information is current as of January 28, 2008}

\section{Updated Information \&} Services

References

Citations

Subspecialty Collections

Permissions \& Licensing

Reprints including high resolution figures, can be found at: http://n.neurology.org/content/70/5/405.full

This article cites 1 articles, 0 of which you can access for free at: http://n.neurology.org/content/70/5/405.full\#ref-list-1

This article has been cited by 2 HighWire-hosted articles: http://n.neurology.org/content/70/5/405.full\#\#otherarticles

This article, along with others on similar topics, appears in the following collection(s):

Vasculitis

http://n.neurology.org/cgi/collection/vasculitis

Information about reproducing this article in parts (figures,tables) or in its entirety can be found online at:

http://www.neurology.org/about/about_the_journal\#permissions

Information about ordering reprints can be found online:

http://n.neurology.org/subscribers/advertise

Neurology ${ }^{\circledR}$ is the official journal of the American Academy of Neurology. Published continuously since 1951, it is now a weekly with 48 issues per year. Copyright . All rights reserved. Print ISSN: 0028-3878. Online ISSN: 1526-632X.

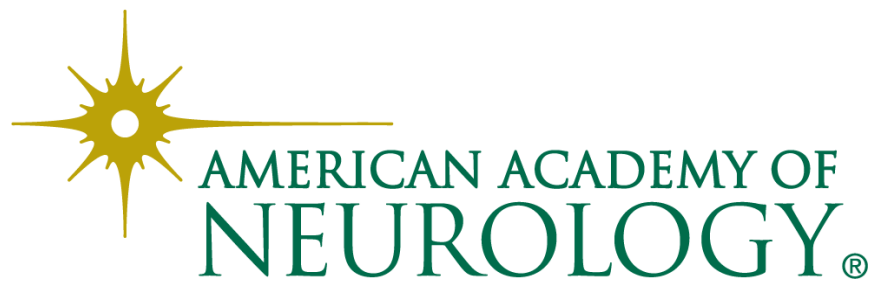

